\title{
CRIMINAL OR FORENSIC INVESTIGATIONS IN SRI LANKA AND THE MEDIA RESPONSIBILITY : THE NEED FOR SUBSTANTIVE MEDIA LAW AND ENFORCEABLE MEDIA ETHICS IN SRI LANKA.
}

\author{
Induwara Gooneratne \\ Dept. of Forensic Medicine, Faculty of Medicine, University of Peradeniya, Sri Lanka
}

\begin{abstract}
This paper seeks to discuss the involvement of media in the criminal or forensic investigation process in Sri Lanka and its possible adverse consequences. Further, this paper attempts to build an argument to establish and propagate media legislation in Sri Lanka especially in reference to crime investigations while emphasising the need for media professionalism, training and enforceable set of media ethics for media personnel and units.
\end{abstract}

The author upholds media freedom. Author reiterates media independence and pluralism in media. However, the right to express is not by any means above the rule of law or right to privacy.

The media law and media ethics in Sri Lanka especially in reference to crime investigations is in its infancy and require a rapid growth immediately to safe guard the rights of victims, suspects and to promote the rule of law.

Keywords: Media Ethics, Medial Law, Forensic Investigation, Criminal Investigation

\section{INTRODUCTION}

Free, fair and a well developed media is a reflection of democracy. However, the freedom of media needs to be exercised with a sense of responsibility, accountability and transparency while upholding the rule of law.

The freedom of expression through the media does not entail a right to override rule of law or another's right to privacy. Rights have equal weights. The limits of one's rights are at the likely embarkation of infringing another's right: a known tenant in the contemporary human rights discourse.

This paper seeks to discuss the involvement of media in the criminal or forensic investigation process in Sri Lanka and its possible adverse consequences. Further, this paper attempts to build an argument to establish and propagate media legislation in Sri Lanka especially in reference to crime investigations while emphasising the need for media professionalism, training and enforceable set of media ethics for media personnel and units.

\section{MATERIALS AND METHOD}

This paper critically analyses two contemporary cases ${ }^{1,2}$. The criminal and forensic investigation process and their media coverage are the point of analogy.

\footnotetext{
${ }^{2}$ http://www.sinhayanews.com/sri-lankan-girlrescued-attempted-suicide last accessed October 2015.

${ }^{1}$ http://www.sundaytimes.lk/150920/news/seyastragedy-the-search-the-discovery-and-heartache164940.html Sunday Times 20 September 2015 Last
} accessed 13.10.2015 


\section{RESULTS AND DISCUSSION}

Publishing details of ongoing criminal or forensic investigations:

\section{The Suspects}

The media both electronic and print media in Sri Lanka are in a consuetude of publishing full details of suspects under investigations. For example, in the recent past, the famous " Seya Sandewmi"'s rape and murder in Kotadeniyawa, Gampaha in September 2015, where a five year old girl was allegedly abducted and raped was fully covered by all local media competitively with all details, photographs, videos and audios. An event of this nature where a little girl is sexually abused and murdered becomes naturally very sensitive, provocative, sad and rageful. The media personnel taking an advantage of the sensitive nature of the event used the victim's fate to advance their financial and media popularity benefit in the name of "media freedom" and in the name of 'informing the truth' to the public, regrettably inconsiderate to the plight the victim, suspects and the family concerned had to go through posthumous. Not limiting to the victim, the media used its power and popularity to target the parents, neighbours and the family.

In a child abuse case, as the literature suggests, the perpetrators are more likely to be a family member, relative or a close associate of the child. I welcome the suspicion the investigators had on the parents or neighbours. However, we must not obliterate the fact that the issue is still under investigation (at the time of writing this article, October 2015) and that so far no one has been found guilty of, by a competent court. The way in which the media portrayed or rather dramatised this incident in the public media creatively made an environment not only for the public to "judge" and incriminate the parents and the rest of other suspects consecutively and perpetually, but also provoked the general public to behave in an unlawful manner. Due to these attributes, the parents were not allowed by the general public to fully involved with the funeral functions. The media, in my opinion, created this irony where the general public became unruly and uncontrollable. Some public and groups may have looked for an opportunity to publicity!

Next in this case, was the arrest of a schoolboy who was in the neighbourhood of Seya, in connection to her rape and murder. $\mathrm{He}$ was under eighteen years of age and should have been considered a juvenile and protected by child rights and juvenile law that applies to children in conflict with the law. It is illegal to show identities of juveniles under criminal investigations. Unfortunately, not only that the media published the name, photographs, videos of arrest and whereabouts of this juvenile suspect accused but also published that he was in the possession of pornographic material in his private computer. This situation is unwarranted and the publicity of these facts of a juvenile suspect should have been avoided. Under both international law and local laws it is expected to keep identities of juvenile's delinquents under strictly confidential and to uphold best interest of the juvenile concerned. The DNA test performed on this juvenile suspect came negative after such a 'drama' created by the media. As a result he was released from further investigations, accordingly.

However, it seems as if the investigators have been oblivious of the fact that a suspect can still have committed a forceful sexual intercourse in this case a statutory rape and/or commit homicide in the absence of a matching DNA profile at the crime scene or on the victim, due to numerous reasons.

The next event in this case was the arrest of "kondaya" a man from a nearby place. According to the media reports he had previous incidents of arrests for alleged sexual abuse of a child. Along with this history and the 'peculiar behaviour' of this 
suspect in the eyes of the media, provided ample momentum for the media to write articles after articles incriminating and judging this suspect along with this man's face pictures and videos of his arrest. The 'looks' of this suspect was not 'ordinary' for some people in the media, while others said he definitely was responsible for the offense due to inter alia a confession made to the police. The media portrayed a prejudice, biased, judgmental opinion about this suspect which convinced many that he was the culprit. The DNA test from this suspect also came negative.

The injuries caused by these actions by the media for the suspects are manyfold. Let alone the mental agony the suspects had to go through during the investigation process, the juvenile suspect had difficulties in attending schools, face bullying and insults from everywhere. The other two suspects too have issues in facing the families, facing the society, finding employment etc. As the names and the photographs of the suspects are published by the local media, the damages caused to the suspects are irreparable.

The actions by the media to publish full identifiable details of the suspect with the photographs and videos of them are not only unethical, but also illegal and unconstitutional. The fundamental rights chapter (chapter 111) of the constitution of the democratic socialist republic of Sri Lanka very clearly stipulates that 'every person should be presumed innocent until proven guilty'. The manner in which the media coverage dispensed the whole scenario of the "Seya" murder case was making a false, prejudicial impression in the public in regard to the criminality of the said accused taken into custody. The media created a platform for the people to judge these suspects given the sensitive nature of the case. The heavy involvement of the media in this case made the general public unrest, as a result the police were stressed and the entire criminal investigation was forced to execute hastily.
Due to the involvement of public agitation after humongous 'media cry' over this issue the suspects have been allegedly tortured and brutalised by police to provide with a confession to suit the media and the investigations. The fact that the media exposition hinted inefficiency of the police in apprehending wrong doers in this case triggered the police to clasp 'someone' to evade imminent embarrassment which inadvertently led the arrest of this juvenile with no justifiable suspicion.

\section{The Victims}

It is regrettable that the media attempts to exhibit the face identity with the traumatic injuries and at times the photographs of the victim child (in this Seya) 'as it is' without clothes. Of course it is financially rewarding to the media as many will want to 'buy' their product to see the pictures or read the 'raw' story. The media deliberately ignores the plight the family and the victim will have to go through with these pictures and videos in public domain.

A few days ago in October 2015, a young adult female jumped into a river in Kandy area allegedly to commit suicide. A few villagers fortunately rescued her. However, the media rushed in to the scene and began to telecast the victim in full details including her face videos disregarding the fact that she attempted to commit suicide presumably undergoing severe mental health issues. The telecasting of this victim's identity will not by any means help the victim to cope with her issues. Such events can be taken to the general public if media so chooses, with more maturity, professionalism and ethics.

\section{The officers involved}

The media categorically expresses the names of the experts who conduct the forensic investigation and the places where the investigations are done. As these are criminal cases, while acknowledging the fact that 
some cases involve underworld and powerful individuals, the expert can be at risk of harm or the evidence collected can be at risk for possible vandalism which may directly affect the administration of justice process.

Furthermore, the jurors and judicial officers who watch or read the creative media stories may have some degree of prejudice or emotion that may be detrimental to administration of justice, hearing or seeing sensitive, traumatic pictures and videos prior to such evidence is presented in the court. The public unrest, public opinion created by the media on such issues in popular media may confound the objective assessment of the evidence. On the other hand certain investigators, institutes or forensic practitioners who crave for cheap media popularity may act or in act to surface his or her media image.

\section{CONCLUSION}

The author upholds media freedom. Author reiterates media independence and pluralism in media. However, the right to express is not by any means above the rule of law or right to privacy. Right to information on the other hand does not entail any right to divulge personal information such as how one lives, eats etc to public which can infringe privacy of a suspect who is supposed to be presumed innocent until proven otherwise. Although media freedom advocates the freedom to consume whatever information or entertainment we want from whatever sources we choose, without government restricting our choices, the limit of freedom as said earlier is the personal rights of others to their privacy, against deformation, against one's dignity and the rule of law respecting the privacy and constitutional rights of an individual.

The media law and media ethics in Sri Lanka especially in reference to crime investigations is in its infancy and require a rapid growth immediately to safe guard the rights of victims, suspects and to promote the rule of law.

Crime reporting can be important to society if and only if they are reported professionally, ethically while safe guarding human rights of victims and suspects upholding the rule of law.

\section{REFERENCES}

1. Santiago, Melanie. "Kotadeniyawa parents appeal for child's safe return as disappearance remains a mystery". News First. Retrieved 5 October 2015.

2. Dissanayake, Ridma. "Seya murder: Teen released". Daily News. Retrieved October 2015.

3. "5-year-old child strangled and sexually molested: JMO". Ada Derana. Retrieved October 2015.

4. Fernando, Lahiru. "New details of Kotadeniyawa child's death revealed". NewsFirst. Retrieved October 2015.

5. "Seya murder: Police arrest another suspect". Ada Derana. Retrieved October 2015.

6. "Kotadeniyawa child murder: first two suspects released". Ada Derana. Retrieved October 2015.

7. Dissanayake, Ridma. "Kondaya reveals gory details of his alleged crime". Daily News. Retrieved 3 October 2015.

8. "Kondaya's DNA deosn't match". Dailymirror. Retrieved 7 October 2015.

9. United Nations Convention of th Rights of the Child, 1989.

10. Beijing Rules- UN Standard Minimum Rules for the administration of Juvenile Justice. 